\title{
Job Motivation as a Mediator in the Relationship Between Job Stress And Job Performance of Police Officers at the Federal Territory Police Headquarters
}

\author{
Kalaikumar Arujunan \\ Faculty of Educational Studies, Universiti Putra Malaysia \\ 43400 UPM Serdang, Selangor, Malaysia \\ Ismi Arif Ismail (Corresponding author) \\ Faculty of Educational Studies, Universiti Putra Malaysia \\ 43400 UPM Serdang, Selangor, Malaysia \\ Shamsuddin Othman \\ Faculty of Educational Studies, Universiti Putra Malaysia \\ 43400 UPM Serdang, Selangor, Malaysia \\ Mohd Mursyid Arshad \\ Faculty of Educational Studies, Universiti Putra Malaysia \\ 43400 UPM Serdang, Selangor, Malaysia
}

Received: Oct. 3, $2021 \quad$ Accepted: Nov. 15, 2021 Online published: Nov. 22, 2021

doi:10.5296/ijhrs.v11i4S.19237ＵRL: https://doi.org/10.5296/ijhrs.v11i4S.19237

\begin{abstract}
Effectiveness of an organization is largely dependent on its employees' job performance. Job performance is influenced by job stress and job motivation, whereby job motivation is believed to have a mediation effect in the relationship between job stress and job performance. Hence, this paper is aimed at identifying the relationship between these three variables among Royal Malaysia Police (PDRM) officers at the Federal Territory Police Headquarters. This is
\end{abstract}


a quantitative study for which data has been collected from 341 police officers through a survey. Data was analyzed statistically using PLS-SEM. Findings showed that there was a significant, negative relationship between job performance and job stress; and between job stress and job motivation. Job motivation was found to be a significant mediator in the relationship between job stress and job performance.

Keywords: job performance, stress, motivation, royal Malaysia police

\section{Introduction}

\subsection{Problem Background}

Job performance includes all activities performed in the execution of a particular job (Chen, 2009). Job performance of employees is an important determinant of organizational effectiveness. However, job performance is believed to be significantly linked to job stress and job motivation. This is because job stress has a direct impact on the quality of job performed by employees as well as affecting their motivation level (Wani, 2013).

Motivation serves as the driving force for a person to perform a job (Noermijati \& Primasari, 2015). Thus, job performance of employees is indirectly influenced by the amount of motivation they receive in an organization. In this context, it is suggested that the effect of job stress on job performance is controlled by job motivation, or in other words, job motivation has a mediating effect on job stress and job performance.

\subsection{Problem Statement}

Policing is one of the most stressed professions in the world. In Malaysia, the Royal Malaysian Police (PDRM) is responsible for law enforcement, order management, maintaining public safety and reduce crime rates (Cheah et al., 2018). Due to the nature of their daily jobs such as long working hours, organizational hierarchy and security issues (Aytac, 2015), police officers are exposed to high job stress in their daily jobs. Prolonged exposure to high job stress has a detrimental effect on police officers' physical and psychological health, as well as their job performance. Nevertheless, motivated police officers are expected to be happier at work and show good job performance despite the job stress (Susan et al, 2012). Therefore, this study is intended to study the mediating effect of job motivation between job performance and job stress of police officers.

\subsection{Objectives of Study}

The study is intended to achieve the objectives to :

i. identify the influence of job stress on job performance.

ii. identify the influence of job stress on motivation

iii. identify the role of motivation as a mediator in influencing the effects of job stress on job performance.

\subsection{Hypotheses of Study}


H1 : There is no significant effect of work stress on job performance.

$\mathrm{H} 2$ : There is no significant effect of work stress on motivation.

H3 : Motivation does not affect the effect of job stress on job performance.

\subsection{Review of Literature}

Job performance is a measure of how a person is performing in his work. Thus, job performance can be used to review, examine and evaluate whether employees' behaviour and performance is aligned to the organizational goals. Employees who demonstrate high level of job performance helps to ensure success of an organization.

Job stress is a common issue at workplace. Job stress is defined as the harmful physical and emotional responses that occur when the requirements of the job do not match the capabilities, resources, or needs of employee (NIOSH, 1999). Thus, work related factors such as high workload and deadlines can cause a person to experience stress and eventually become less productive in workplace.

On the other hand, motivation is capable of triggering and reinforcing a behaviour or action (Dobre, 2013). Motivation has been closely associated to job performance. According to Asim (2013), there is a positive correlation between motivation and employees' job performance. The higher is the employees' motivation, the higher would be their job performance. This is linked to the willingness of employees to 'invest' time and effort in their job, which leads to higher job commitment and productivity (Shkoler \& Kimura, 2020). As such, organizations with motivated employees are often more successful because employees will always find ways to perform their tasks effectively (De Jong \& Den Hartog, 2007). Motivated employees also support the achievement of organizational goals because they will always find ways to improve their job performance (Razali et al., 2021).

Besides, motivation has also been associated to employees' level of job stress. It is being suggested that enhancing motivation could be an important technique for reducing job stress of employees. It is generally believed that when employees are adequately motivated, they will be more satisfied and happier to work for an organization (Unnikrishnan, 2015). This may eventually increase organizational productivity and competitiveness However, there is still limited literature on how motivation actually regulates job stress of employees as most of the previous studies had been focused on investigating the impact of job stress on motivation, not vice-versa. 
1.6 Conceptual Framework

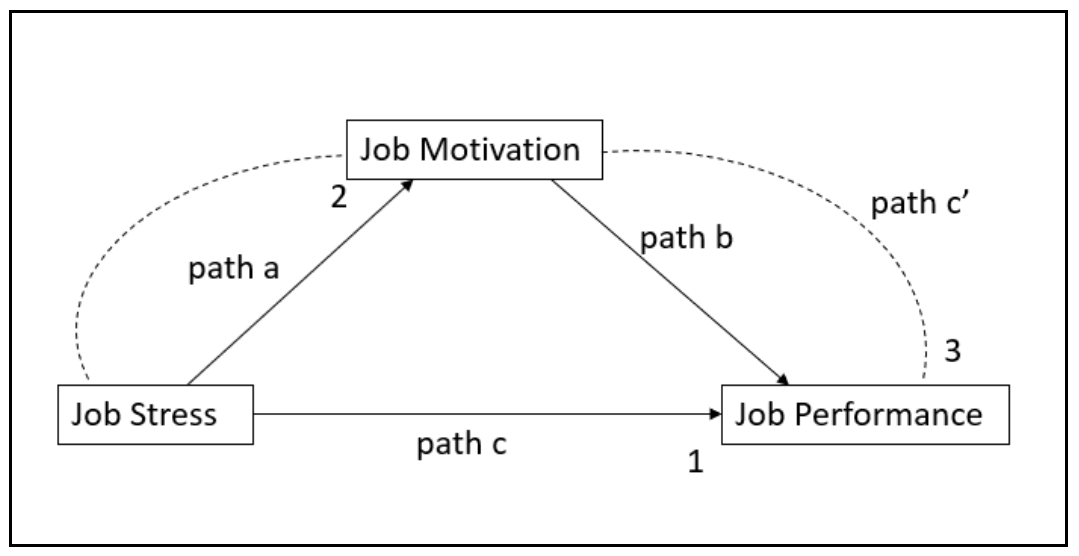

In this conceptual framework, job stress is referred to as the 'predictor', job performance as 'criterion' while job motivation as 'mediator'. According to the framework, there is a direct relationship between job performance and job stress (path c); job stress and job motivation (path a) and job performance and job motivation (path b). Nevertheless, an indirect relationship is stipulated between job stress and job performance, with job motivation acting as a mediator (path c').

According to Baron \& Kenny (1986), mediation effect is calculated using three regression equations: (i) predictor effect on criterion (path c), (ii) predictor effect on the mediator (path a) and (iii) predictor and mediator effect on criterion (path $\mathrm{c}^{\prime}$ ). The next step is to compare the standard regression coefficients $(\beta)$ for paths $c$ and c' and if $\beta$ at $c$ is smaller, then mediation occurs. In other words, after the calculation of the three equations, perfect mediation occurs when the direct effect (path c) is non-existent and the indirect effect (path c') exists; partial mediation occurs when both direct and indirect effects exist (Baron \& Kenny, 1986).

\section{Method}

This quantitative study was conducted using survey methodology to collect data. A total of 341 samples were obtained using purposive sampling from the population of PDRM officers at the Federal Territory Police Headquarters. A questionnaire with Likert-scales items was employed as instrument to collect data. For job performance', 18 items on a 5-point Likert scale were used to record respondents' scores ranging from 1-Rarely/Never to 5Always/Often. For job stress, 'Occupational Stress Index' containing 46 items on a 5-point Likert scale was used with responses ranging from 1-Strongly Disagree to 5-Strongly Agree. For motivation, 'Extrinsic and Intrinsic Motives Work Scale' with 16 items on a 7-point Likert scale was used to obtain respondents' scores ranging from 1-Not Appropriate at All to 7-Appropriate and Accurate. Data from the completed questionnaire was then analyzed statistically with PLS-SEM software. 
Table 1. Individual Job Performance

\begin{tabular}{|l|l|}
\hline No. & Item \\
\hline 1 & I manage to plan my work so that I can complete it on time \\
\hline 2 & My work planning is optimum \\
\hline 3 & I remember the outcome that I need to achieve in my job \\
\hline 4 & I am able to identify main problems in my work place \\
\hline 5 & I can complete my job with minimum utilization of time and effort \\
\hline 6 & I take extra responsibilities at work \\
\hline 7 & I start new tasks on my own once I am done with the previous ones \\
\hline 8 & I take up challenging tasks \\
\hline 9 & I work to ensure that my job-related knowledge is up-to-date \\
\hline 10 & I work to maintain my job-related skills \\
\hline 11 & I can provide creative solutions for problems \\
\hline 12 & I keep on looking for challenges in my job \\
\hline 13 & I am active during work meetings \\
\hline 14 & I complain about unimportant matters at school \\
\hline 15 & I am a trouble maker at work \\
\hline 16 & I always focus on the negative aspects of my job \\
\hline 17 & I talk to my colleagues regarding negative aspects of my work \\
\hline 18 & I talk to outsiders on negative aspects of the work/organization \\
\hline
\end{tabular}

Table 2. Occupational Stress Index

\begin{tabular}{|l|l|}
\hline No & Item \\
\hline 1 & I need to do a lot of work in this job \\
\hline 2 & $\begin{array}{l}\text { There is inadequate and vague information on my job role and its } \\
\text { expected outcome }\end{array}$ \\
\hline 3 & $\begin{array}{l}\text { I often receive contradicting work instructions from different } \\
\text { supervisors }\end{array}$ \\
\hline 4 & $\begin{array}{l}\text { It is sometimes difficult to coordinate between group pressure and } \\
\text { formal instructions/regulation }\end{array}$ \\
\hline 5 & I feel responsible for being efficient and productive at work \\
\hline 6 & $\begin{array}{l}\text { My suggestions are often being considered and implemented in this } \\
\text { organization }\end{array}$ \\
\hline 7 & $\begin{array}{l}\text { My decision and instructions on job segregation among employees } \\
\text { are being followed }\end{array}$ \\
\hline 8 & I need to cooperate with people I like \\
\hline 9 & My job involves observational tasks \\
\hline 10 & Top management of this organization is concerned about my welfare \\
\hline 11 & I receive lower salary for the job I do \\
\hline 12 & I do my job under pressure \\
\hline 13 & I have to manage additional workload with insufficient manpower \\
\hline
\end{tabular}




\begin{tabular}{|c|c|}
\hline & and resources \\
\hline 14 & The objectives of my job role are clear and well-documented \\
\hline 15 & My supervisors do not interfere in my job scope and work method \\
\hline 16 & I have to work unintentionally due to group pressure \\
\hline 17 & I am responsible for the future of some workers \\
\hline 18 & $\begin{array}{l}\text { My contribution is often sought after in the process of resolving } \\
\text { problems at workplace }\end{array}$ \\
\hline 19 & $\begin{array}{l}\text { My suggestions on employee training and development are often } \\
\text { being considered }\end{array}$ \\
\hline 20 & $\begin{array}{l}\text { Some of my colleagues and subordinates try to downgrade my work } \\
\text { performance }\end{array}$ \\
\hline 21 & $\begin{array}{l}\text { I have unlimited opportunities to utilize my expertise and experience } \\
\text { in my current job }\end{array}$ \\
\hline 22 & This job has improved my social status \\
\hline 23 & I seldom get recognition for my work performance \\
\hline 24 & My job is risky and complicated \\
\hline 25 & I often have to do my job in hurry because of heavy workload \\
\hline 26 & $\begin{array}{l}\text { I cannot perform my job smoothly due to vague job scope and job } \\
\text { descriptions }\end{array}$ \\
\hline 27 & $\begin{array}{l}\text { I am not provided with clear instructions and adequate resources } \\
\text { when assigned with new tasks }\end{array}$ \\
\hline 28 & I have to go extra miles in my job in order to be accepted in a group \\
\hline 29 & I am responsible for the success of this organization \\
\hline 30 & I am involved in policy making of the organization \\
\hline 31 & $\begin{array}{l}\text { Input and feedback from employees must be taken into consideration } \\
\text { before conducting interviews for important positions }\end{array}$ \\
\hline 32 & $\begin{array}{l}\text { My colleagues cooperate with me well in resolving problems at work } \\
\text { place }\end{array}$ \\
\hline 33 & I can develop my capabilities in this organization \\
\hline 34 & The top management does not acknowledge my job and position \\
\hline 35 & I often feel that this job has made my life difficult \\
\hline 36 & $\begin{array}{l}\text { I am unable to spend time and attention for my personal life as I am } \\
\text { too busy with my job }\end{array}$ \\
\hline 37 & $\begin{array}{l}\text { I am not sure what my colleagues and top management expect of job } \\
\text { role and behaviour at work }\end{array}$ \\
\hline 38 & Employees need to focus on work procedures and formal instructions \\
\hline 39 & $\begin{array}{l}\text { I am forced to break organizational rules and procedures at times due } \\
\text { to group pressure }\end{array}$ \\
\hline 40 & $\begin{array}{l}\text { My opinions are taken into consideration for any improvement or } \\
\text { amendments in the work system or instrument }\end{array}$ \\
\hline 41 & $\begin{array}{l}\text { There is high cooperation and team work among employees in this } \\
\text { organization }\end{array}$ \\
\hline
\end{tabular}


42 My recommendations for problem solving are not taken into consideration although I am capable in my job

43 The working condition in this organization is good, especially in terms of employee welfare and facilities

$44 \quad$ I need to do the same work as others

45 It is difficult to implement new procedures and policies in the organization

$46 \quad$ I cannot do my job well because of too high workload and too little time

Table 3. Extrinsic and Intrinsic Motives Work Scale

\begin{tabular}{|l|l|}
\hline No & Item \\
\hline 1 & I choose this job to achieve a particular life style \\
\hline 2 & I choose this job for the income \\
\hline 3 & I can complete the tasks related to this job \\
\hline 4 & I am happy as I get to learn new things from this job \\
\hline 5 & The job has become part of myself \\
\hline 6 & I will be ashamed of myself if I could not succeed in this job \\
\hline 7 & I choose this job to achieve my career goal \\
\hline 8 & The job is an interesting challenge \\
\hline 9 & The job gives me money \\
\hline 10 & The job is the way I want my life to be \\
\hline 11 & I will be disappointed if I cannot perform in this job \\
\hline 12 & I do not understand why we are given unrealistic job requirements \\
\hline 13 & I can be a 'winner' in life through this job \\
\hline 14 & It is a satisfaction when I manage to do difficult tasks \\
\hline 15 & This job offers safety and security to me \\
\hline 16 & There is a high expectation on my job \\
\hline
\end{tabular}

\section{Results}

\subsection{Sociodemographic Profile of Respondents}

Table 4. Sociodemographic Profile of Respondents

\begin{tabular}{lll}
\hline Characteristics & Frequency & $\%$ \\
Gender & & \\
Male & 277 & 81.2 \\
Female & 64 & 18.8 \\
& & \\
Age & & \\
$20-30$ & 20 & 5.9 \\
\hline
\end{tabular}


$31-40$

$41-50$

51 and above

Marital status

Single

Married

Education level

STPM/Diploma

Bachelor degree

Masters degree

$\mathrm{PhD}$

Rank

INSP - ASP

262

65

11

$\mathrm{ACP}-\mathrm{SAC}$

DCP and above

Monthly income (RM)

$2500-4500$
$4501-6500$
$6501-8500$
8501 and above

15.0

$161 \quad 47.2$

$79 \quad 23.2$

$50 \quad 14.7$

Length of service (years)

\begin{tabular}{lll}
10 or less & 80 & 23.5 \\
$11-20$ & 134 & 39.3 \\
$21-30$ & 64 & 18.8 \\
31 and more & 63 & 18.5 \\
\hline
\end{tabular}

Majority of the study respondents were male (81.2\%), indicating that career as police officers is dominated by men over women. Most of the respondents were aged between 31 to 40 years (49.9\%), followed by 41 to 50 years $(22.6 \%)$ and 51 years and above $(21.7 \%)$. Majority $(89.1 \%)$ of respondents were married and a total of $39.3 \%$ had served as a police officer for 11 to 20 years. In terms of education level, majority (47.8\%) respondents had a Bachelor's Degree. Apart from that, majority of the respondents held the rank of INSP to ASP (76.8\%), with monthly salary between RM 4501 to RM 6500 . 
3.2 Descriptive Analysis of Job stress, Job Performance and Job Motivation

Table 5. Descriptive analysis of variables

\begin{tabular}{llll}
\hline & Mean & SD & Level \\
\hline Job stress & 2.87 & 0.48 & Moderate \\
Job performance & 3.71 & 0.56 & High \\
Job motivation & 3.76 & 0.62 & High \\
\hline
\end{tabular}

Job stress and job performance of police officers was found to be at a moderate and high level, respectively. Job motivation was also found to be high among the police officers.

\subsection{Relationship Between Job Stress, Job Performance and Job Motivation}

Table 6. Relationship between variables

\begin{tabular}{|c|c|c|c|c|c|c|}
\hline Path & $\boldsymbol{\beta}$ & Mean & SD & t & $95 \% \mathrm{CI}$ & $\mathbf{p}$ \\
\hline \multicolumn{7}{|l|}{ Direct effect } \\
\hline Job stress $\rightarrow$ Job performance & -0.458 & -0.453 & 0.056 & 8.152 & $-0.540,-0.358$ & $<0.001$ \\
\hline Job stress $\rightarrow$ Job motivation & -0.311 & -0.331 & 0.081 & 3.846 & $-0.455,-0.208$ & $<0.001$ \\
\hline Job motivation $\rightarrow$ Job performance & 0.317 & 0.321 & 0.054 & 5.838 & $0.209,0.430$ & $<0.001$ \\
\hline \multicolumn{7}{|l|}{ Indirect effect } \\
\hline $\begin{array}{l}\text { Job stress } \rightarrow \text { Job Motivation } \\
\rightarrow \text { Job performance }\end{array}$ & -0.099 & -0.105 & 0.031 & 3.181 & $-0.163,-0.059$ & 0.002 \\
\hline
\end{tabular}

Path coefficient analysis showed a negative relationship between job stress and job performance with $\beta=0.458,95 \% \mathrm{CI}=0.540,0.358, \mathrm{t}$-value $=8.152$, while job stress also showed a negative relationship with job motivation with $\beta=0.311,95 \% \mathrm{CI}=0.455,0.208, \mathrm{t}$ -value $=3.846$. Therefore, hypothesis $\mathrm{H} 1$ which states that there is no significant effect of job stress on job performance was rejected. Additionally, hypothesis $\mathrm{H} 2$ which states that there is no significant effect of job stress on job motivation was also rejected. Additionally, a positive relationship was shown between job motivation and job performance with $\beta=0.317,95 \% \mathrm{CI}$ $=0.209,0.430, \mathrm{t}$ value $=5.838$. Path coefficient analysis also showed a significant relationship between job stress, job motivation and job performance, whereby job motivation was found to be a significant mediator in the relationship between work stress and job performance with $\beta=0.099,95 \% \mathrm{CI}=0.163,0.059, \mathrm{t}$-value $=3.181$.

\section{Discussion}

This study showed that job motivation can increase the level of job performance among police officers despite facing job stress. The more motivated and committed police officers are to their jobs, the less they perceive their work as stressful. This suggests that self-determined motivation can protect police officers from experiencing the negative impacts of stress through its effect on stress assessment. According to Ghazinour et al., (2021), stress can be considered a challenge or a threat. Folkman (1997) proposed that a situation is 
considered a threat only if the situation exceeds individual resources. Police officers who are motivated to work may have more psychological resources; and therefore, experience less job stress than others. As such, motivation whether from supervisors and organization can reduce stress levels and improve the job performance of police officers.

On top of that, self-determined motivation was positively associated with significant work-related consequences. Firstly, it is reflected in employees' work intention. The more motivated employees are to their jobs, the more they report an intention to continue working for as long as possible before they retire (Landry et al., 2017; Hutagalung et al., 2020; Herdiany, 2019). These findings have important implications for police officers and police organizations. Police officers who leave the team before actual retirement will have to look for alternative career and may not be able to fully enjoy their pension plan. For PDRM, voluntary resignation means the loss of experienced officers, after which energy and time must be spent on hiring and training new officers (Chen, 2018).

On overall, job motivation is associated with feelings of interest, confidence, and freedom to continue working. Thus, job motivation may allow police officers to work in a stressful environment while experiencing only limited impacts of the stress. This finding is consistent with Kulachai and Arnaraphibal's (2017) model related to motivation, stress and coping, which suggests that motivation help individuals to regard stressful events as a challenge rather than a threat as they have better personal goals and values, which they expect others to respect. On overall, the findings of this study may conclude that there was a significant effect of job stress on job performance; and job stress on job motivation. A negative relationship between job stress and job performance indicates that high job stress may reduce job performance of police officers. Similarly, the negative relationship between job stress and job motivation indicates that high job stress may lower job motivation among the police officers. There is also a significant relationship between job stress, job motivation and job performance, whereby job motivation was found to have a mediation effect in the relationship between job stress and job performance.

\section{Acknowledgement}

The authors wish to thank all the PDRM officers who participated in this study.

\section{References}

Aytac, T. (2015) The Effect of Gender on Teachers' Job Satisfaction: A Meta-analysis, The Anthropologist, 20(3), 385-396. https://doi.org/10.1080/09720073.2015.11891742

Baron, R. M., \& Kenny, D. A. (1986). The moderator-mediator variable distinction in social psychological research: Conceptual, strategic, and statistical considerations. Journal of $\begin{array}{llll}\text { Personality and Social } & \text { Psychology, } & \text { 51(6), }\end{array}$ https://doi.org/10.1037/0022-3514.51.6.1173

Cheah, P. K., Unnithan, N. P. \& Suppiah, S. (2018). Role reflections of police reservists: a study of volunteer reserve officers in Malaysia. Policing: An International Journal, 41(6), 813-827. https://doi.org/10.1108/PIJPSM-05-2017-0065 


\section{Macrothink}

International Journal of Human Resource Studies

ISSN 2162-3058

2021, Vol. 11, No. 4S

Chen, Y-F. (2009). Job Stress and Performance: A Study of Police Officers in Central Taiwan.

Social Behavior and Personality: an international journal, 37, 1341-1356. https://doi.org/10.2224/sbp.2009.37.10.1341

Chen, Z. (2018). Job satisfaction among frontline police officers in China: The role of demographic, work-related, organizational and social factors. Psychology, Crime \& Law, 24(9), 895-914. https://doi.org/10.1080/1068316X.2018.1442835

De Jong, J. P., \& Den Hartog, D. N. (2007). How Leaders Influence Employees' Innovative Behaviour. European Journal of Innovation Management, 10, 41-64. https://doi.org/10.1108/14601060710720546

Dobre, O. I. (2013). Employee motivation and organizational performance. Review of Applied Socio-Economic Research, 5(1), 53.

Folkman, S. (1997). Positive psychological states and coping with severe stress. Social Science and Medicine, 45, 1207-21. https://doi.org/10.1016/S0277-9536(97)00040-3

Ghazinour, M., Padyab, M., \& Hansson, J. (2021). Police stress in the swedish context: Development and psychometric properties of the police stress identification questionnaire. $\begin{array}{lllll}\text { Nordic Journal of Studies in } & \text { Policing, } & 8(1) \text {. }\end{array}$ https://doi.org/10.18261/issn.2703-7045-2021-01-05

Herdiany, H. D. (2019). Effect of Stress, Organizational Culture, Motivation on Organizational Citizenship Behaviour at Pati Police Resort. Bisman (Bisnis dan Manajemen): The Journal of Business and Management, 2(2), 119-130.

Hutagalung, R. K., Purba, E. N., Silalahi, J. T., \& Putri, A. (2020). The Effect of Competence, Work Ethic, Work Discipline, and Work

Kulachai, W., \& Amaraphibal, A. (2017). Developing a causal model of turnover intention of police officers in the eastern region of Thailand. International Journal of Arts \& Sciences, 10(1), 473-486.

Landry, A. T., Gagné, M., Forest, J., Guerrero, S., Séguin, M., \& Papachristopoulos, K. (2017). The relation between financial incentives, motivation, and performance. Journal of personnel Psychology.

National Institute of Occupational Safety and Health (NIOSH) (1999). Available online from: www.cdc.gov/niosh/docs/99-101

Noermijati, \& Primasari, D. (2015). The effect of job stress and job motivation on employees performance through job satisfaction (A study at PT. Jasa Marga (Persero) Tbk. Surabaya Gempol branch ). Journal of Economics, Business and Accountancy Ventura, 18(1), 231-240. https://doi.org/10.14414/jebav.v18i2.450

Razali, F., Rami, A. A. M., Nazuri, N. S., \& Suhaimi, S. S. A. (2021). Relationship Between Leadership, Resilience, and Competence Amongst Police Officers in Klang Valley, Malaysia. Asian Social Science, 17(11), 39-47. https://doi.org/10.5539/ass.v17n11p39 


\section{Copyright Disclaimer}

Copyright for this article is retained by the author(s), with first publication rights granted to the journal.

This is an open-access article distributed under the terms and conditions of the Creative Commons Attribution license (http://creativecommons.org/licenses/by/4.0/). 